\title{
Teaching and critically reflective practice in Freire
}

\author{
Leon Benade \\ School of Education \\ Auckland University of Technology \\ Auckland, New Zealand \\ lbenade@aut.ac.nz
}

\section{Introduction}

Few of the many books written by Freire drew particular, and extended, attention to the teacher in the way Pedagogy of Freedom (1998) was able to do. While this entry draws on many other important works by Freire, it specifically probes elements of this book to place before readers some of the salient qualities and attributes Freire believed teachers, educators and thinkers of education ought to aspire to.

There are four themes of relevance here. The first is Freire's commitment to the idea of teaching as a political activity, particularly in the context of the contemporary neoliberal grind, which was widely evident across multiple nations by the time of his death in 1997. The second is that teaching could be, indeed should be, regarded as an ethical activity, and this entry explores that claim. It is an important claim to uphold in a climate that increasingly regards teachers to be mere functionaries of the state and its pursuit of 'achievement objectives' for the $21^{\text {st }}$ century labor market.

Freire is well known for his, sometimes controversial, position on the development of a critical consciousness. Relating ideas about the development of a critical consciousness to teachers and teaching leads to a double consideration: first, teachers have a role in initiating their students into the process of developing criticality, and second, teachers have a responsibility to both themselves and their profession to develop as critically reflective practitioners. Both roles will be dealt with in the second half of this entry.

Before advancing any further, however, it will be helpful to review some of the central ideas contained in Freire's concept of teaching as a profession. He regarded teaching to be a vocation that was "mysterious," and the reason for the devotion of teachers (p. 126). Freire believed that the individual teacher has "consciously taken [the] option to intervene in the world" (p. 122), and for him this was no mystery. Freire's words highlight the ethical nature of intrinsically valuable work of teaching professionals who focus on matters of great significance to people and their lives. In this context, it may be understood why Freire stated unequivocally that teachers must struggle "to bring dignity to the practice of teaching" (p. 64). These commitments demanded of teachers may, however, be discomforting to some. 


\section{Teaching is a political activity}

Not all teachers (especially beginning ones) may immediately comprehend the direct influence of policy on their professional lives. Becoming aware of the role of policy, and coming to realise that teachers have the potential to challenge the effects of those policies, does, however, reveal teaching to be a political activity. One of the most important ways in which policy has influenced teaching, was the (infamous) 'No Child Left Behind' (NCLB) policy of the United States administration of George W. Bush. It was an example of policy reflecting a reaction to public (and political) perceptions of a systemic failure in education to deliver a return on taxpayer investment (namely students successfully navigating the school system and being deemed 'employable').

Paulo Freire argued that modernising, reformist policies in education (such as NCLB) spawned a "neoliberal technoscientific education," creating a false dichotomy between the need for a broader liberating education and the narrow economic intentions of vocationalism (1996, p. 131). Freire's Pedagogy of Freedom (1998) revealed his concern with the impact of the "scourge of neoliberalism" (p. 22) on teachers' thought and practice. The fatalistic ideology of neoliberalism encourages teachers to see the world as a given, discouraging theorising of its underlying causes and tensions, giving preference instead to data manipulation as an explanatory tool. The neoliberal agenda thus places enormous emphasis on the accumulation of grades through continuous assessment. The promise of a hopeful education that develops a love of society and consequently, egalitarian tendencies, is no more than a vain hope under these policy agendas. Instead, what these policies do teach is acceptance of growing socio-economic disparities that consign most students to a narrow vocational life (Freire, 2005).

In the face of this, teachers of courage and love have the "right and duty to opt" (Freire, 1998, p, 53) and "consciously [take the] option to intervene in the world" (p. 122). Thus, Freire contended that there is no neutral pedagogy (Shor \& Freire 1987), and so when they take up a position, teachers commit to making a difference to the lives of their students. One sense in which this proposition can be understood is for educators to recognize that their role is more influential than merely teaching content-their role includes the moral formation of learners (Freire, 1998), which cannot be separated from teaching content.

As teaching occurs in a socio-political and economic policy context, it is further appropriate for teachers to display their respect for the socio-cultural location of their students. Teachers have a direct influence on the cultural formation of students. This role may be particularly important to teachers helping their students to survive in a world they find alienating, and one that often denies the cultural background of students, or subsumes this background in the mainstream culture. Confronting these political realities presupposes that teachers exercise ethical care and love for their students. 


\section{Teaching is an ethical activity}

Teaching is people-centered, and draws heavily on, and significantly influences, human motivations, desires, beliefs and goals. The relationships that develop in an educative context are therefore complex, and so Freire wanted teachers to note, "it is not possible to imagine the human condition disconnected from the ethical condition" $(1998,39)$. Therefore, teaching, Freire would argue, is an ethical activity.

Freire believed it not possible to be a teacher who educates, while at the same time, avoiding the development of an attitude of love and care towards students (1998). So much so, he believed it the duty of teachers to be knowledgeable of the background of their students. This entails coming to understand first-hand of the daily living conditions of students and the context of their socio-economic lives:

It's impossible to talk of respect for students...without taking into consideration the conditions in which they are living and the importance of all the knowledge derived from life experience, which they bring with them to school. I can in no way underestimate such knowledge. (1998, p. 62)

In classrooms that emphasize relationships, mutual trust between teachers and students will grow from the coherence of the actions and words of teachers. "Children are extremely sensitive to teachers who do exactly the opposite of what they say" (Freire, 2005, p. 98). Therefore, Freire accentuated teachers' actions over their words (actions speak louder than words) but ethical teachers must strive to ensure their words and deeds cohere. When, however, unethical choices are made, such as violating trust, then the relationships that exist in a school community are violated.

The ethical teacher is disposed to listening. This implies a focus on what is being said, rather than a focus on speaking or, as Freire ([1970] 1996) has it, delivering 'communiqués'. A focus on listening over speaking does not silence the teacher's voice, but allows the student voice that is struggling to make meaning and sense of knowledge. To create the climate in which this student voice can be heard requires a spirit of humility on the part of the teacher (Freire, 1998), although this does not imply the submission of the teacher. By being an active listener, however, the teacher models appropriate behavior for students to follow in their relations with teachers.

Freire challenged the deepening instrumentality of teaching, suggesting that "to transform the experience of educating into a matter of simple technique is to impoverish what is fundamentally human in this experience: namely, its capacity to form the human person" (1998, p. 39). Thus, teaching is not a technical matter, Freire suggesting that to "educate is essentially to form" (p. 39). Teachers therefore engage in a task that is both richly ethical, yet radically uncertain. This state of uncertainty was captured by one of Freire's well-known notions, that 
humans are never complete, thus he was committed to an ontology of teaching that recognized teachers to be in a state of ever-becoming (1998).

A final point of relevance to the idea of teaching as an ethical profession is what Freire had to say about power imbalances, possibly a reality of all classrooms, even democratic ones. Freire wanted teachers to respect the curiosity of students by not crushing their spirit. The ethical teacher respects "the dignity, autonomy, and identity of the student" (1998, p. 62), bringing "dignity to the practice of teaching" (p. 64). Needless to say, this is a challenging call, given the obvious power imbalances between (younger, less experienced and less knowledgeable) students and teachers who are older, more experienced and (possibly) more knowledgeable.

\section{III.Commitment to developing critical thinking in students}

In his famed Pedagogy of the Oppressed (1970/1996), Freire rejected 'banking education' in favor of 'problem-posing education', a rejection he reiterated in Pedagogy of Freedom (1998). He was thus condemning a transmission style of teaching in favor of a dialogical education that would develop critical epistemological curiosity $(1970 / 1996$; 1998), or, in other words, a critical disposition (1976). In Freire's notion of problem-posing pedagogy, the life experience and prior knowledge of students become a text, or authentic context, in the development of knowledge and critical understanding. Problem-posing teachers demand academic rigor, yet also realize that students are always "recreating and remaking" knowledge (1998, p. 31). Thus, problem-posing teachers will seek ways to bridge the body of existing knowledge with that which students have and bring with them, to ensure their students cross over from ingenuous curiosity to critical curiosity and consciousness.

Students should not have to engage in this development of critical understanding alone, or unaided. Rather, they require an "educator with a democratic vision or posture [who] cannot avoid...insisting on the critical capacity, curiosity, and autonomy of the learner" (p. 33). Therefore, it is important, argued Freire, for teachers to be reminded of their responsibility to promote and develop critical thinking: "The teacher needs to model an active, skeptical learner in the classroom who invites students to be curious and critical...and creative" (Shor \& Freire 1987, p. 8).

Developing the critical thinking of students does not take place in a vacuum, and if students are to think critically, they must think about something. Specifically this will be the knowledge of the curriculum and the knowledge of the students. It is important therefore that teachers must see themselves, and be seen, as authorities in their field of expertise (Freire, 1998; Freire \& Macedo, 1987; and Macedo, 2000). This position is, however, counterbalanced by Freire's insistence that democratic educators are not elitists or authoritarians (1985). Authoritative teachers ensure that minimum knowledge content is made available so that each student is equipped, not only for a gainful and meaningful life, but a critically reflective one too. On the assumption that there is no value-free pedagogy (Shor 
\& Freire, 1987), teachers seeking to develop the critical thinking of their students will problematize concrete human relations as a precursor to the development of critical consciousness (Freire, 1970).

Teachers are challenged by a policy climate of accountability, and a demand for ever-increased student attainment, and may thus choose to ignore Freire's behest to support students in developing their ability to become critically aware of their world. Or they can engage with the democratic import implicit in the promise of problem-posing education. Critically reflective teachers can achieve this goal for their students by demanding academic rigor and having the expectation that all their students can benefit by this rigor. Thus "a culture of excellence and justice" (Duncan-Andrade \& Morrell, 2008, p. 172) pervades the classroom, replacing low expectations and discrimination.

There are, however, dangers here. The notion of 'critical thinking' is one that has become popularized by many national and state curriculum documents. As an example, see the New Zealand Curriculum (Ministry of Education [MOE], 2007), which is significantly influenced by the 'key competencies' research of the Organisation for Economic Co-operation and Development (OECD) (see Benade, 2012; OECD, 2003). This curriculum makes only one reference to 'critical thinking' (MOE, 2007, p. 23), but uses the terms 'critical' and 'critically' eighteen times, and 'thinking' 20 times, this in a document with only 43 pages of curriculum-relevant text. This policy outlines five key competencies for schools to focus on, one of which is 'thinking'. So far, this seems laudable, but the detail yields a somewhat different message, where 'thinking' is defined as "using creative, critical, and metacognitive processes to make sense of information, experiences and ideas" (p. 12). Positively, this thinking should encourage students to "challenge the basis of assumptions and perceptions", but may end up being little more than "developing understanding...constructing knowledge...[and]...reflect[ing] on their own learning” (p. 12).

Therefore, caution is advocated, as Freire's notion of 'critical consciousness' is not equivalent to the suggestions advocated by this curriculum document in relation to 'thinking' or 'thinking critically'. It can be seen how Freire's concept can be domesticated though, and it has been pointed out before (Roberts, 2000) that Freire's notion of critical consciousness is linked to his praxis of humanization-the ideal that all people will attain their ontological ideal of becoming more fully human through liberation. The on-going search for humanization is an on-going search for critical consciousness of the changing material world, to reflect on that world, and to transform it accordingly (2000). That is somewhat different to thinking about thinking.

\section{IV.Teachers' reflective practice}

Not only are teachers 'unfinished' (Freire, 1998), as are all humans, but by virtue of their exercise of an option to intervene in an imperfect world, they commit 
themselves to bring about transformative change. Therefore, the daily practice of teaching suggests that the identity of a teaching professional is actively forged and developed, and is constantly evolving. In Pedagogy of Freedom (1998), Freire clearly intended that teachers be open to change and new ideas, through critical reflection. This reflective activity will support teachers to be consistent in their work, so that there is no incoherence of word and deed (1998). As we have seen, this coherence builds trust in the classroom. Coherent teachers are characterized by their "right thinking" (p. 40), which is developed not in one-off bursts, but rather through regular and consistent practice. Such an approach "demands a seriousness in the search for secure and solid bases for his/her positions" (p. 40).

Freire noted on several occasions in Pedagogy of Freedom (1998) that action precedes theory; that a critically reflective teacher is open to change and novelty, and, of course, that both the words and deeds and theory and practice of a teacher must be coherent. Critical reflection on practice is thus central to Freire's theory. When teachers think critically about their present practice, their future practice will benefit, and they develop their theoretical understanding of their own purpose as educators. In Freire's own words: "My theoretical explanation of [educational] practice ought to be also a concrete and practical demonstration of what I am saying" (p. 49). This interaction between practice and theory was termed 'praxis' by Freire. An explicit Freirean strategy of praxis involves: problem identification; problem analysis; creation of a plan of action to address the problem; implementation of the plan; analysis and evaluation of the action (Duncan-Andrade \& Morrell, 2008). This process supports teachers in their own research and knowledge development, and its action-orientation is in keeping with Freire's view that reflective activity has the potential to transform the world (1976).

Praxis may thus also be understood as a process of critical self-reflection. Underlying this pedagogical approach is the teacher's commitment to students "recreating and remaking" knowledge (Freire, 1998, p. 31). A further underlying feature of praxis is wrestling with the differences of ability among students, who are not all ready to learn at the same time. Through a process of reflection, selfreflective teachers theorize their practice, then try out their emerging theories as they gear classroom programs in such a way that students can bridge the gap from ingenuous to critical curiosity.

As self-critical learners, and problem-posing educators, teachers research their students as if they were themselves 'texts'. Teachers seek to understand their students much as a reader seeks to understand a text. It is especially important that a teacher seek to understand the meanings their students construct. In doing so, teachers must demonstrate their respect for the dignity of their students, and their acceptance of the idea that the moral formation of students cannot be separated from the teaching of content (1998).

Therefore, it may be seen that praxis, as a way of understanding critical reflection on practice, is morally informed and committed to transformative action. A focus on the relationship between theory and practice by teachers as 
part of their daily routine helps to challenge the technical and instrumental rationality pervading education in the $21^{\text {st }}$ century. Praxis is a resolution of the tensions that exist between theory and practice, enabling teachers to develop new approaches to knowledge and understanding, based on their interpretation of their students and what they know, existing knowledge, and the unique contexts of their classrooms.

\section{Conclusion}

In Pedagogy of Freedom (1998), Freire explicitly addressed himself to what it means to be a teacher. In so doing, he implicitly and explicitly provided a sense of what it means to be a professional in the context of the early $21^{\text {st }}$ century that is dominated by an agenda driven by economic concerns. These concerns have been referred to here as neoliberalism, which Freire labeled a "scourge" (p. 28). The neoliberal agenda for education is reformist modernization, often played out in education as a demand for greater student achievement against a backdrop of data accumulation and accountability requirements. Too often, teachers meekly acquiesce-but Freire called for courage and set out a number of priorities for teachers.

Teaching is not a neutral activity, and demands that teachers take up a position-on this point, Freire was clear. Ideally, the position he wanted teachers to take up is that of a critical, democratic and progressive educator. In particular, he wanted teachers to be culturally responsive to their students, and to contribute to their cultural formation. This position presupposes an orientation of love and care towards students, and this exhortation draws attention to teaching as an ethical activity. Teachers would have to be mindful of the inevitable power imbalances in their classrooms, and work to overcome this challenge. In so doing, teachers commit themselves to keeping to the fore the dignity of their students as human beings. Teachers have other commitments beside. They must show the way so that their students develop as critical thinkers who know and understand their world, so that, like their teachers they may choose to intervene and transform their world. Finally, teachers cannot be helpful in supporting their students to become critical thinkers and doers, unless they too, are models of critical reflection and action. Freire, a man grounded in the day-to-day of his students' lives, recognized the significance of practice, yet believed theory to be significant in shaping practice. There are tensions and contradictions in the relationship between theory and practice, and Freire's emphasis on praxis attempted to alert teachers to the dialectical ebb and flow between practice and theory, and theory and practice.

Freire's simple humility and respect for the dignity of others, and his driving passion for the attainment of a just world in the face of a global orientation that emphasizes greed, self-aggrandizement and individual attainment over social cohesion, serve as an object lesson to all educators, and a model for all teachers to emulate. 


\section{Cross-References}

Conscientization and the Cultivation of Conscience by Liu, K

Critical Pedagogy, Historical Origins of by Cho, $\mathrm{S}$.

Dewey on Thinking in Education by English, A.

Dewey on Teaching and Teacher Education by Greenwalt, K.

Dewey and Critical Pedagogy

by Lamons, B.

Dewey on Ethics and Moral Education by Simpson, D

Dialogue in Critical Pedagogy by Burbules, $\mathrm{N}$.

North American Critical Pedagogy by Lampert, $\mathrm{M}$. 


\section{References}

Benade, L. (2012). From technicians to teachers: Ethical teaching in the context of globalized education reform. New York, NY/London, United Kingdom: Continuum.

Duncan-Andrade, J.M.R., \& Morrell, E. (2008). The art of critical pedagogy: Possibilities for moving from theory to practice in urban schools. New York, NY: Peter Lang.

Freire, P. (1970/1996). Pedagogy of the oppressed (M. B. Ramos, Trans.). London, England: Penguin Books. Citations refer to the 1996 edition.

Freire, P. (1976). Education, the practice of freedom (M. B. Ramos, Trans.). London, England: Writers and Readers Collective.

Freire, P. (1985). The politics of education: Culture, power and liberation. London, England: Macmillan.

Freire, P. (1996). Letters to Cristina: Reflections on my life and work (D. Macedo with Q. Macedo \& A. Oliveira, Trans.). New York, NY: Routledge.

Freire, P. (1998). Pedagogy of freedom: Ethics, democracy and civic courage. Lanham, MD: Rowman and Little.

Freire, P. (2005). Teachers as cultural workers: Letters to those who dare teach (D. Macedo, D. Koike \& A. Oliveira, Trans.). Cambridge, MA: Westview Press.

Freire, P., \& Macedo, D. (1987). Literacy: Reading the word and the world. London, England: Routledge and Kegan Paul.

Macedo, D. (2000). Introduction to the Anniversary Edition. In P. Freire, Pedagogy of the oppressed, translated by (M. B. Ramos, Trans.) (pp. 1128). New York, NY: Continuum.

Ministry of Education. (2007). The New Zealand Curriculum. Wellington, New Zealand: Learning Media Limited. Also available from http://nzcurriculum.tki.org.nz/The-New-Zealand-Curriculum

Organisation for Economic Cooperation and Development (OECD). (2003). Definition and selection of competencies: Theoretical and conceptual foundations (DeSeCo): Executive Summary. Retrieved from http://www.oecd.org/pisa/35070367.pdf

Roberts, P. (2000). Education, literacy, and humanization: An introduction to the work of Paulo Freire . Westport, CT: Greenwood Press.

Shor, I \& Freire P. (1987). A pedagogy of liberation. London, England: Bergin \& Garvey. 
